RESEÑA

\title{
Carlos Sanmartín Barberi
}

\section{2 - 1996}

\begin{abstract}
"Quiero que mi cuerpo sea sepultado directamente en la tierra, sin caja mortuoria $y$ apenas envuelto en un sudario. Quiero reintegrarme rápida y enteramente a la madre nutricia primigenia. Me gustaría resurgir al mundo en las bellas flores que lo adornan, en los pastos de los prados, en esa fascinante vida de la flora y fauna ocultas que están activas permanentemente y para siempre. Tengo tres maravillosos hijos y dos hermosos nietos; espero que tengan de mí un recuerdo grato. En ellos me siento perpetuado y confío que, para no desaparecer del todo de este mundo, sean los autores de nuevas generaciones que algo tendrán de lo que fui."
\end{abstract}

Este párrafo es tomado de una carta que dejó Carlos Sanmartín Barberi a Roberto, su hermano menor, pocos meses antes de morir. Quienes lo hayan conocido entenderán que dibujan bastante bien la atractiva personalidad de este científico colombiano nacido en Bogotá el 12 de abril de 1922 y fallecido el 6 de diciembre de 1996. Fuera de su esposa Clara y Jaime, Mauricio y Diego, sus tres hijos, tenía sus tres hermanas Maruja, Cecilia y Helena y a Roberto, con quienes compartía un humor especial y divertido para analizar el comportamiento humano.

Perteneció a una familia de gente ilustre en la cual se destacaron médicos de nombre; recibió su título de médico en la Universidad Nacional de Colombia en 1948 y prestó su servicio obligatorio como médico rural con la empresa de petróleo Shell de Colombia en los Llanos Orientales y el Magdalena medio. Después de un año de trabajo en el Instituto Finlay de Bogotá, ganó una beca del Consejo Británico para estudiar un año en el London School of Hygiene and Tropical Medicine. Su carrera profesional fue brillante y tuvo siempre una inclinación muy clara por la salud pública, en particular, por las llamadas enfermedades emergentes, muy en boga por esta época que vivimos.

El doctor Sanmartín ocupó siempre posiciones nacionales e internacionales destacadas. Regresó de Inglaterra como jefe de laboratorio del Instituto Finlay, ocupando ese cargo desde 1950 hasta 1954. Sus responsabilidades incluían el estudio de la epidemiología de los virus transmitidos por artrópodos que apenas comenzaban a descubrirse y la preparación de la vacuna contra la fiebre amarilla que se usaba en el país y que, además, se distribuía a otros países de Latinoamérica y Africa. Por aquella época y en colaboración con Hernando Groot y Ernesto Osorno, demostró por

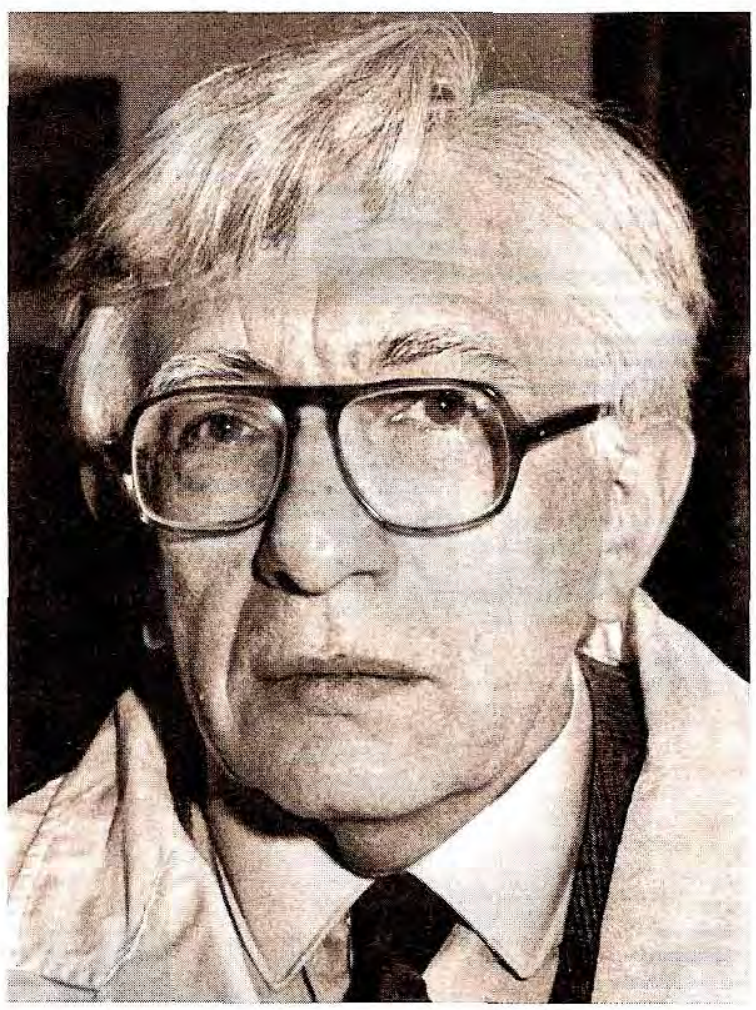


primera vez que, en condiciones naturales, el virus de la encefalitis equina venezolana podía afectar al ser humano, causando grandes epidemias. Este hallazgo se hizo a raíz de una epidemia de fiebre que hubo en 1952 en El Espinal, Tolima, en la cual, además de inocular los ratones de experimentación que se habían llevado para el estudio, se inoculó él con el suero de dos enfermos. Así fue como consiguió aislar el virus tanto en los ratones que murieron al segundo día de inoculados como en él mismo, al desarrollar una enfermedad que él mismo pudo describir.

Posteriormente, trabajó con Max Theiler y Wilbur Downs en los laboratorios que tenía la Fundación Rockefeller en Nueva York y en Trinidad, respectivamente, en desarrollo de una beca otorgada por la Fundación Rockefeller. En 1955, regresó a Colombia como profesor de virología y de medicina preventiva en la Facultad de Medicina de la Universidad del Valle. Allí continuó estudiando los arbovirus en colaboración con la Fundación Rockefeller y estableció un laboratorio de campo sobre el río Raposo, en las selvas del Pacífico colombiano, en donde se aislaron arbovirus hasta entonces desconocidos. En 1967, describió por primera vez con Ronald Mackenzie, Harold Trapido y Pablo Barreto, una epizootia del virus venezolano de encefalitis equina asociada a epidemia, ocurrida en Cali y sus alrededores. Hizo una detallada descripción de todos los artrópodos, animales domésticos y animales silvestres involucrados en dicha epidemia, incluyendo aves, mamíferos y reptiles. En este trabajo, que sigue siendo una pieza de consulta obligatoria en la materia, señaló el papel que tienen los equinos como enormes amplificadores en la transmisión de este virus, hecho que aclaró la magnitud devastadora que tienen estas epizootias y epidemias. Durante este período, se destaca también la descripción que hizo con el doctor Trapido del virus Pichindé, único Arenaviridae aislado hasta la fecha en Colombia, el cual ha servido de modelo experimental en la virología moderna por tratarse de un virus inocuo para el nombre.

Fue conferencista de la Academia Eslovaca de Ciencias en la ciudad de Smolenice en 1966 y fue el invitado especial para la XXXVII Conferencia Anual Charles Franklin Craig de la American Society of Tropical Medicine and Hygiene de 1972 , la cual tituló Experiencias epidemiológicas en subpaíses superdesarrollados. En esta charla, criticaba el doctor Sanmartín, ilustrando con ejemplos patéticos y en su lenguaje muy particular, el imperdonable prurito que existe en nuestros países latinos de comprar equipos sofisticados y muy costosos que jamás se utilizan y terminan empolvados en el rincón de los laboratorios o de los depósitos, cuando la solución de los problemas estructurales económicos y sociales más elementales de salud siguen años atrás.

Posteriormente viajó a Buenos Aires como epidemiólogo consultor de enfermedades virales para el Centro Panamericano de Zoonosis de la Organización Panamericana de la Salud, en donde trabajó hasta 1976. Siguió trabajando en el mismo cargo con la OPS en Caracas hasta 1982. Durante este período, fue el invitado honorario en el Congreso de Directores de Laboratorios de Salud Pública que tuvo lugar en Washington, D.C., E.U.A., en 1977. Finalmente, regresó a Colombia como Director del Instituto Nacional de Salud en 1982.

Fue, también, profesor de medicina de la Universidad Nacional de Colombia, miembro del Comité Asesor de Malaria de la Organización Mundial de la Salud y Miembro Honorario de la Academia Colombiana de Medicina.

Carlos Sanmartín creía que el nuestro es un mundo maravilloso al cual sentía orgullo de haber pertenecido porque, usando sus propias palabras, disirutó de cosas tan hermosas como el amor, la música, el arte, la amistad sincera, las noches estrelladas, la grandiosidad de la selva tropical.

Fue profesor y amigo muy singular, decía cosas que no se olvidan y de él recibí valiosos consejos que sigo ponderando porque cambiaron el rumbo de mi vida profesional. Fue una personalidad y un gran hombre cuya muerte entristece a su familia y a sus amigos. 